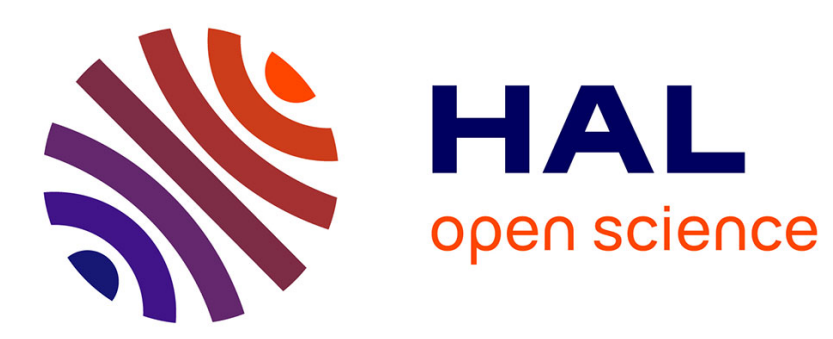

\title{
Science Information and the complexity: are we oriented to a transdisciplinary science?
}

Rafaela Carolina da Silva, Rosângela Formentini Caldas

\section{To cite this version:}

Rafaela Carolina da Silva, Rosângela Formentini Caldas. Science Information and the complexity: are we oriented to a transdisciplinary science?. CS-DC'15 World e-conference, Sep 2015, Tempe, United States. hal-01291102

\section{HAL Id: hal-01291102 \\ https://hal.science/hal-01291102}

Submitted on 20 Mar 2016

HAL is a multi-disciplinary open access archive for the deposit and dissemination of scientific research documents, whether they are published or not. The documents may come from teaching and research institutions in France or abroad, or from public or private research centers.
L'archive ouverte pluridisciplinaire HAL, est destinée au dépôt et à la diffusion de documents scientifiques de niveau recherche, publiés ou non, émanant des établissements d'enseignement et de recherche français ou étrangers, des laboratoires publics ou privés. 
Abstract

• "Multi-Level Modeling" e-track

\title{
Science Information and the complexity: are we oriented to a transdisciplinary science?
}

\author{
Rafaela Carolina da Silva \\ Master's student in Program in Information Science at Unesp/Marília - Brazil \\ Rosângela Formentini Caldas \\ Ph.D in Information Science Department at Unesp/Marilia - Brazil
}

Keywords: Complexity. Transdisciplinarity. Complex Science. Transdisciplinary Science. Information Science.

The concept of transdisciplinarity is an extent of complex expression in society. Currently, the human, social and phychological contexts are connected and the science needs an answer about this phenomenon. This article conceptualizes the transdisciplinarity as a strategic application of complexity, which is a theorical and methodological concept that bases the transdisciplinarity.

Then, the concepts of transdisciplinarity and complexity connected, since we understand transdisciplinary as fundamental question relat to complex structures inherent in the world. This idea also leads the thinking of a design that considers a new perception of reality. According to Morin (2001, p. 138, our translation), understand the complexity is "[...] at the same time, separate, associate [...] the emergency of levels reality without reducing them to elementary units and general laws".

In this context, "Transdisciplinarity as the prefix 'trans' indicates, indicates that is a relation between the disciplines, across different disciplines and beyond any discipline. This goal is the understanding of this world for which one of the imperatives is the unity of knowledge." (NICOLESCU, 1997, s.n, our translation).

So, the question is: "Is the Information Science oriented to a transdisciplinarity sicence?" It's depends of the object that we are studying. If we study the object and think that the object of Information Science is the information, it can be a transdisciplinary object. We can see that the literature of Information Science hasn't a conceptualization of what information would be. In other hand, if you concept that your object of study are the various types of applications that information professionals realize in the library, so we can discuss other concepts, as multidisciplinarity, pluridisciplinarity and interdisciplinarity.

We can observe the Figure 1, relating interdisciplinarity, pluridisciplinarity and multidisciplinarity, the transdisciplinarity is multireferential and multidimensional, taking concepts of time and history in a transhistorical horizon (Transdisciplinarity Letter, 1994). 
Figure 1: Interdisciplinarity, pluridisciplinarity, multidisciplinarity and transdisciplinarity

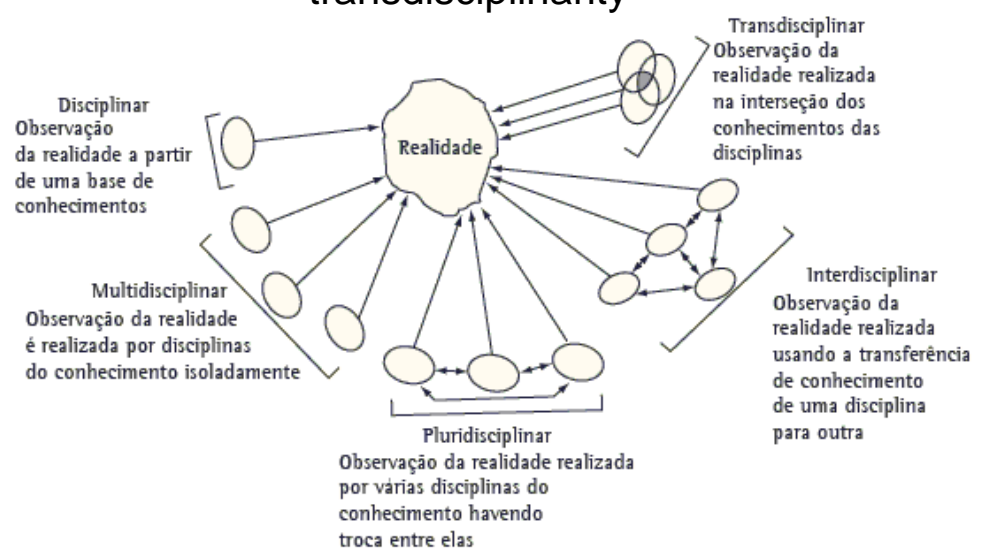

Source: larozinski Neto; Leite (2010. p.4).

For Information Science can be considered as transdisciplinary science, there must be a change in the perception of phenomenon, society, reality, ethics, etc. In this perspective, is how the professional exercises his profession that designates if a science is multi/pluri/inter or transdisciplinary.

Finally, this paper aims to propose a discussion about the theme instead of try to conceptualize transdisciplinarity. It's a question that impacts all the world in a complexity system of emotions, rights, rationality, humans relations and contexts.

\section{Scientific Validation}

This paper has been unanimously validated in a collaborative review mode with the following reviewers:

- Paul Rodriguez

- Ricardo Fernandes, from Centre of Research, Education, Innovation and Intervention in Sport, Faculty of Sport and Porto Biomechanics Laboratory, University of Porto, Porto, Portugal

- Lukasz Lacinski, University of Chicago

\section{References}

CARTA DE TRANSDISCIPLINARIDADE. In: PRIMEIRO CONGRESSO MUNDIAL DA TRANSDISCIPLINARIDADE. Convento de Arrábida, Portugal, 2-6 novembro 1994.

IAROZINSKI NETO, A.; LEITE, M. S. A abordagem sistêmica na pesquisa em engenharia de produção. Produção, v.20, n.1, jan./mar. 2010, p. 1-14.

MORIN, E. Ciência com consciência. 5.ed. Rio de Janeiro; Bertrand, 2001.

NICOLESCU, B. A evolução transdisciplinar a universidade: condição para o desenvolvimento sustentável. In: Congresso Internacional "A Responsabilidade da Universidade para com a Sociedade", 1., 1997, Bangkok. Anais... Bangkok: International Association of Universities; Chulalongkorn University, 1997. Disponível em: <http://ciret-transdisciplinarity.org/bulletin/b12c8 por.phps. Acesso em: 05 jun. 2015. 